2. Смоляр О. А. Державний контроль у сфері місцевого самоврядування: особливості правового регулювання. Проблеми законності. 2015. Вип. 129. С. 59-68. URL: http://nbuv.gov.ua/ UJRN/Pz_2015_129_9

3. EMESE PÁL Models of Legal Supervision over Local SelfGovernments in Continental Europe (Excluding France). Pécs Journal of International and European Law. 2018/II p. 6-20. URL: http://ceere.eu/pjiel/wp-content/uploads/2019/03/emese-1.pdf

4. Gemeindeordnung für das Land Nordrhein-Westfalen (GO NRW).URL: https://recht.nrw.de/lmi/owa/br_text_anzeigen?v_id=23200 21205103438063\#FV

5. Про місцевий уряд: зведений закон Данії від 24 жовтня 2006 р. № 1060. URL: http://www.csi.org.ua/www/?p=2414

6. Zakon o lokalni samoupravi. Uradni list RS, št.94/07 (uradno prečiščeno besedilo) URL: http://pisrs.si/Pis.web/pregledPredpisa?id= ZAKO307

DOI https://doi.org/10.30525/978-9934-588-92-1-21

\title{
ПРИНЦИП ЗАГАЛЬНОГО ВИБОРЧОГО ПРАВА: МІЖНАРОДНІ СТАНДАРТИ ТА ПЕРСПЕКТИВИ ЗАКОНОДАВЧОЇ РЕАЛІЗАЦЇ̈ В УКРАЇНІ
}

\author{
Гудзь Л. В. \\ кандидат юридичних наук, доцент, \\ доцент кафедри конституційного і муніципального права \\ юридичного факультету \\ Харківського національного університету імені В. Н. Каразіна \\ м. Харків, Україна
}

Принцип загального виборчого права означає, що громадяни можуть обирати і бути обраними після досягнення відповідного віку незалежно від статі, кольору шкіри, національності, ставлення до релігії і переконань, а також, як правило, незалежно від майнового i посадового становища. Значення цього принципу для державотворення ще на початку XX ст. яскраво підкреслив відомий учений-правник Б. Кістяківський, який говорив: «Немає нічого, що такою мірою забезпечувало б державну єдність і національну солідарність, як 
загальне виборче право» [1, с. 679]. Тобто, основна функція принципу загального виборчого права - визначення кола носіїв (суб'єктів) відповідного суб'єктивного виборчого права.

Загальне виборче право може обмежуватися за ознакою громадянства (ценз громадянства), що обумовлюється політичним характером цього суб'єктивного права. Причому для наявності виборчого права ставляться вимоги про наявність громадянства як на день виборів, так і протягом встановленого строку. Наприклад, згідно 3 національним законодавством США, сенатор Конгресу повинен бути громадянином США не менше 9 років, депутат палати представників не менше 7 років, а Президент США повинен бути громадянином за народженням [2, с. 15-17]. В Угорщині, Фінляндії та Іспанії на місцевих виборах виборче право мають іноземні громадяни, які проживають на території країни протягом певного часу та своєчасно сплачують податки [3, с. 372].

Загальне виборче право обмежується за віковим цензом. Заняття виборних посад i прийняття рішення на виборах вимагають відповідного рівня знань, умінь і навичок. На сьогоднішній день у більшості країн світу по відношенню до активного виборчого права віковий ценз становить 18 років.

Для пасивного виборчого права віковий ценз вищий. Наприклад, щоб обійняти посаду Президента в Італії необхідно досягти п'ятдесятирічного віку [4, с. 260]. В Екваторіальній Гвінеї - з 45 років, в Єгипті, Йорданії, Кувейті та Туреччині - 330 років. У двох країнах передбачена «вилка» вікових обмежень для кандидатів: Екваторіальна Гвінея - з 45 до 60, Іран - з 26 до 75 років [5, с. 66]. Зміст вікового цензу треба розуміти таким чином, що для здійснення управління потрібен досвід, уміння, навички при вирішенні життєвих ситуацій.

Українське законодавство встановлює різні вікові цензи залежно від виду виборів. Так, відповідно до ст. 76 Конституції України та ст. 134 Виборчого кодексу України, народним депутатом може бути обраний громадянин України, який на день виборів досяг 21 року. Президентом України відповідно до ст. 103 Конституції України та ст. 75 Виборчого кодексу України може бути обраний громадянин України, який досяг 35 років. Депутатом та сільським, селищним, міським головою може бути обраний громадянин України, який має право голосу і на день виборів досяг 18 років відповідно до ст.70 Конституції України та ст. 193 Виборчого кодексу України.

На нашу думку, віковий ценз для депутатів місцевих рад та сільських, селищних, міських голів повинен бути збільшений до 21 року, оскільки громадяни, які досягли 18 річного віку, ще не мають 
відповідного досвіду, освіти та навичок для вирішення життєвих ситуацій і заняття відповідної посади. Також, на нашу думку, доцільним було б встановлення вікового цензу для народних депутатів України на рівні 25 років, оскільки 21 рік не забезпечує навіть отримання вищої освіти, об'єктивно кажучи, потрібної для такої кваліфікації.

Загальне виборче право обмежується у разі, якщо громадянина буде визнано судом недієздатним. Частина 2 статті 70 Конституції України говорить про те, що не мають права голосу громадяни, яких визнано судом недієздатними. Питання про визнання громадянина недієздатним вирішуе суд згідно зі статтею 39 Цивільного кодексу України [6]. Єдиною підставою визнання громадянина недієздатним є те, що він унаслідок хронічного, стійкого психічного розладу не здатний усвідомлювати значення своїх дій або керувати ними. Причому під дієздатністю розуміється здатність своїми діями набувати для себе цивільні права і самостійно їх здійснювати, а також здатність своїми діями створювати для себе цивільні обов'язки, самостійно їх виконувати та нести відповідальність у разі їх невиконання (ст. 30 Цивільного кодексу України). Порядок визнання громадянина недієздатним регламентований цивільно-процесуальним законодавством (розділ 4 Цивільно-процесуального кодексу) [7]. Над такою особою встановлюється опіка, але опікун не має права від імені громадянина здійснювати виборче право.

У контексті вітчизняного виборчого права слід зауважити, що конституційна норма, яка позбавляє права голосу лише осіб недієздатних, не суперечить правовим позиціям Європейського суду 3 прав людини, а отже, статті 3 Першого протоколу. Проте така норма не враховує широкого спектру особливостей стану осіб, цивільна дієздатність яких обмежена.

У виборчій практиці зарубіжних країн непоодиноким є застосування морального цензу, який стосується реалізації активного і пасивного права громадян. Моральний ценз, який стосується реалізації громадянами свого пасивного виборчого права, полягає в тому, що не може бути обраний на виборну посаду громадянин, який має судимість за вчинення умисного злочину, якщо ця судимість не погашена і не знята у встановленому законом порядку.

Практика вирішення даної проблеми в зарубіжних країнах достатньо відпрацьована. Так, у Перу, згідно з Органічним законом про вибори 1997 р. громадянин може бути позбавлений виборчого права (активного і пасивного) за постановою суду як наслідок покарання за кожний злочин. Закон Азербайджанської Республіки «Про вибори до 94 
Національних зборів Азербайджанської Республіки» 1997 р. у статті 3 встановлює, що не можуть бути обрані депутатами Національних зборів, незалежно від погашення судимості, особи, засуджені за тяжкі злочини $[8$, с. 78]. Федеральний закон «Про основні гарантії виборчих прав і права на участь у референдумі громадян Російської Федерації” 1997 p. передбачає, що у разі наявності у кандидата незнятої i непогашеної судимості у підписному листі і виборчому бюлетені повинні вказуватися номер і назва статті Кримінального кодексу Росії, на підставі якої був засуджений кандидат [9, с. 29].

В Україні цей механізм є недостатньо відпрацьованим, оскільки на різних видах виборів встановлюється різний порядок застосування морального цензу. Частина третя статті 76 Конституції встановлює дискваліфікаційну умову щодо пасивного виборчого права на виборах народних депутатів України та місцевих виборах - наявність судимості за вчинення умисного злочину, не знятої i не погашеної у встановленому законом порядку. Але відповідне обмеження відсутнє у статті 103 Конституції, яка встановлює кваліфікаційні вимоги щодо балотування на пост Президента України. Протягом тривалого часу така конституційна «прогалина» компенсувалася законодавцем шляхом встановлення відповідного обмеження пасивного виборчого права на виборах Президента України відповідним Законом. 3 прийняттям Виборчого кодексу України ст. 75 якого не передбачає такого обмеження, тобто балотуватися на посаду Президента України може особа, яка має судимість.

На нашу думку, таких підхід $є$ неприйнятним і ст. 103 Конституції України та ст. 75 Виборчого кодексу України потребує змін i встановлення по-перше єдиного підходу щодо порядку застосування морального цензу і по-друге не може бути обрана на посаду особа, яка вчинила кримінально караний злочин, а отже перебуває у правовому конфлікті із державою. Це дозволяє виборцям зробити правильний вибір і обмежити доступ особам, які намагаються отримати виборну посаду i використовувати посадове становище у своїх інтересах. Законодавство повинно створити максимальну кількість обмежень для кримінальних елементів на шляху до влади. Враховуючи такі обставини, проведення виборчої реформи повинно бути спрямоване недопущення криміналізації органів державної влади і місцевого самоврядування. Крім того, ми вважаємо за необхідне взагалі запровадити заборону бути обраним на виборну посаду для громадян, які мають судимість за вчинення умисного злочину, навіть якщо ця судимість $\epsilon$ погашеною або знятою. 


\title{
Література:
}

1. Кістяківський Б.О. Вибране. К. : Абрис, 1990. 680 с.

2. Конституция зарубежных государств: Конституция США 1787 г. M., 1996. C. 15-17.

3. Чиркин В. Е. Российская конституция и международный опыт. Государство и право. 1992. № 12. С. 13.

4. Конституции зарубежных государств : Конституция Италии 1947 г. М., 1996. 260 с.

5. Конституционное право: словарь. отв. ред. В.В. Маклаков. М.: Юристь, 2001. 166 с.

6. Цивільний кодекс України від 16.01.2003 року № 435-IV [Електронний ресурс]. - Режим доступу: https://zakon.rada.gov.ua/ laws/show/435-15\#Text

7. Цивільний процесуальний кодекс від 18.03.2004 року № 1618-IV [Електронний ресурс]. - Режим доступу: https://zakon.rada.gov.ua/ laws/show/1618-15\#Text

8. Веденеев Ю. А. Новое избирательное право РФ: проблемы развития и механизм реформирования. Вестник Центральной избирательной комиссии РФ. 1997. С. 78.

9. Ковлер А.И. Франція : партия и избиратели. М., 1984. 256 с.

DOI https://doi.org/10.30525/978-9934-588-92-1-22

\section{ДО ПИТАННЯ ЩОДО КАТАЛОГУ АБСОЛЮТНИХ ПРАВ ЛЮДИНИ В КОНСТИТУЦЙНОМУ ЗАКОНОДАВСТВІ УКРАЇНИ ТА МІЖНАРОДНИХ АКТАХ}

\author{
Дахова I. I. \\ кандидат юридичних наук, \\ дочент кафедри конституиійного права Украӥни \\ Національного юридичного університету імені Ярослава Мудрого \\ м. Харків, Україна
}

Як відомо, з огляду на можливість обмеження реалізації прав і свобод, вони поділяються на абсолютні (що не можуть бути обмежені в жодному випадку) та відносні. Аналіз Конституції та законодавства України, юридичних позицій Конституційного Суду України, а також міжнародних актів і практики ЄСПЛ, дозволяє стверджувати, що 